\title{
Effects of sediment organic content and hydrodynamic conditions on the growth and distribution of Zostera marina
}

\author{
E. Caroline Wicks ${ }^{1,2, *}$, Evamaria W. Koch ${ }^{2}$, Judy M. O'Neil ${ }^{2}$, Kahla Elliston ${ }^{2,3}$ \\ ${ }^{1}$ NOAA-UMCES Partnership, NCBO-Cooperative Oxford Laboratory, 904 South Morris Street, Oxford, Maryland 21654, USA \\ ${ }^{2}$ Horn Point Laboratory, University of Maryland Center for Environmental Science, 2020 Horns Point Road, Cambridge, \\ Maryland 21613, USA \\ ${ }^{3}$ Biology Department, 3258 Texas A \& M University, College Station, Texas 78843, USA
}

\begin{abstract}
The hypothesis that sediment organic content is limiting growth and distribution of the seagrass Zostera marina was tested in Chincoteague Bay, Maryland, and in a controlled mesocosm experiment. In the field, $Z$. marina was usually absent from areas with sediment organic content $>4 \%$, especially compared with areas with sediment organic content $<4 \%$. In contrast, in a mesocosm experiment, $Z$. marina thrived in organic rich (4 to 6\%) sediment, developing long leaves and disproportionately short roots. Such plants have high drag and low anchoring capacity. As a result, Z. marina plants grown in organic rich sediment are more likely to be dislodged than are plants grown in organic poor sand. We hypothesize that when organic rich sediments are found in hydrodynamically active areas, a mismatch occurs between plant morphology and the physical environment, leading to the loss of seagrasses due to uprooting. Therefore, sediment organic content limitations in seagrass habitats need to be evaluated within the local hydrodynamic settings. Fine organic sediment may be less limiting to seagrasses in quiescent waters while sand with low organic content may be required for seagrass survival in hydrodynamically active areas.
\end{abstract}

KEY WORDS: Seagrass · Zostera marina · Eelgrass · Sediment organic content · Salt marsh · Sediments $\cdot$ Morphology $\cdot$ Nitrogen fixation

\section{INTRODUCTION}

The distribution of seagrasses along coastlines is determined not only by water depth (Duarte 1991) and light availability (Dennison et al. 1993), but also by temperature, salinity, wave exposure (Fonseca \& Bell 1998), current velocity and sediment characteristics (Koch 2001). While temperature and salinity determine which species will be present in an area (den Hartog 1970), waves and currents determine the presence or absence of seagrasses in areas where sufficient light is available (Koch 2001). Sediment composition, i.e. amount of sand or mud, affects sediment geochemistry and microbial nutrient dynamics such as nitrogen fixation, which in turn can also affect seagrass growth
(Capone 1982, Short 1987, Murray et al. 1992, Perry \& Dennison 1999). Sediment organic content plays a major role in microbial nutrient dynamics. For example, organic rich sediments appear to have higher numbers of diazotrophs (nitrogen fixing bacteria) than organic poor sediments (O'Neil \& Capone 1989). Seagrasses themselves also influence microbial nutrient dynamics by exuding organic compounds in the rhizosphere, increasing heterotrophic bacterial nitrogen fixation, which may in turn provide more nitrogen for seagrass growth (Perry \& Dennison 1999).

Although extensive research has been done on the effect of light on seagrasses and, to a lesser extent, on the effect of temperature, salinity, currents and waves on seagrasses, fewer studies have investigated 
whether sediment characteristics limit the growth and distribution of seagrasses. The studies that have been performed have focused on sediment porewater nutrients (Short 1983, Murray et al. 1992) or hydrogen sulfide (Carlson et al. 1994, Brueechert \& Pratt 1996). Porewater nutrient concentrations are closely related to sediment organic content (Berner 1977). Organic poor sediments, such as sand, are considered to be nutrient limiting to seagrasses due to low levels of ammonium and phosphate (Holmer et al. 2001). Conversely, organic rich sediments, such as mud, typically have high amounts of ammonium and phosphate (Berner 1977). Hydrogen sulfide can be toxic to seagrasses, but usually only when another environmental stressor (e.g. low light, high temperature) is present and sulfide levels are higher than normally found in healthy seagrass beds ( $6 \mathrm{mM}$, Koch \& Erskine 2001). In contrast to porewater nutrients and hydrogen sulfide, sediment composition (organic content and grain size) has not been studied extensively. Such data are important for understanding the synergistic effects of sediment type, geochemistry and dynamics on seagrass growth and distribution.

The motivation for this study was the observation of a variety of sediment types from old marsh peat (a result of marsh retreat) to sand (from eroding dunes) in subtidal seagrass habitats in Chincoteague Bay, Maryland, USA, and the fact that the sediments adjacent to retreating marshes appear to be unvegetated. Therefore, our hypothesis stated that the organic content of subtidal sediments adjacent to retreating marshes (i.e. old marsh peat as the substrate in seagrass habitats) limits seagrass growth. This hypothesis was tested using a combination of in situ observations and controlled experiments.

\section{MATERIALS AND METHODS}

Study site. Chincoteague Bay is a lagoonal system, characterized by shallow depths $(<6 \mathrm{~m})$, restricted flushing and limited freshwater input (Wazniak \& Hall 2005). Mill's Island in Chincoteague Bay (Fig. 1) was selected as our study site based on the presence of seagrasses, specifically Zostera marina, as well as a variety of sediment types in a relatively small area. This is the result of substantial marsh retreat $\left(0.59 \mathrm{~m} \mathrm{yr}^{-1}\right)$ over the past century (Wicks 2005) leading to marsh loss and erosion of a local dune (Fig. 1). The present study took place at the southeast portion of the island, along a beach extending from southwest to northeast. The substrate in the seagrass habitat (i.e. $<1 \mathrm{~m}$ water depth) along the southeast shoreline was dominated by old marsh peat where seagrasses were absent, and a sand layer $(1 \mathrm{~mm}$ to $>10 \mathrm{~cm})$ over old marsh peat where seagrasses were present (Fig. 1). Old marsh peat is the term we use to describe highly compacted, clay sediment that has been buried by marsh processes (accretion) over decades. There is little or no refractory marsh material (not quantified) remaining in this sediment. Due to sea level rise, marsh plants are dying in this area (Stevenson et al. 2002) making the marsh more vulnerable to erosion. As the marsh erodes due to wave action and more frequent flooding, the shoreline retreats exposing marsh peat, which becomes the subtidal seagrass habitat. The old marsh peat is covered with sand in some locations. The source of sand in the study area is an eroding dune within the marsh system (Fig. 1), a common process in the area (Rosen 1980). The sand from the eroding dune is carried by currents, deposited over the subtidal old marsh peat and reworked by waves. The astronomical tidal range at the study site is less than $30 \mathrm{~cm}$ (i.e. microtidal) and the salinity ranges from 18 to 35 (Wazniak \& Hall 2005).

Light availability. To assure that shoreline erosion was not increasing turbidity near shore to the point that light was limiting to seagrasses, the spatial variability of light availability was determined on July 6 , 2004. Light measurements (LICOR LI 193 spherical underwater sensor) and GPS coordinates (eTrex, Garmin International; accuracy $= \pm 3 \mathrm{~m}$ ) were taken at 5 points along each of 10 transects that ran perpendicular to the shoreline. This ensured that the entire area where seagrasses could be growing along the southeast side of Mill's Island was covered. Using the Lambert-Beer equation $-K_{d}=-\ln \left(I_{0} / I_{z}\right) / z$, where $I_{0}$ is the light just below the surface, $I_{z}$ is the light at depth $(z)$ and $z$ is the difference in depth between $I_{0}$ and $I_{z}-$ the light attenuation coefficient $\left(K_{d}\right)$ was calculated based on light measurements at $0.2 \mathrm{~m}\left(I_{0}\right)$ and $1.4 \mathrm{~m}\left(I_{z}\right)$ below the surface.

Field surveys. Field surveys and aerial photographs showed the seagrass bed to be narrow and to follow the shoreline. In August 2004, sediment samples (cores $5 \mathrm{~cm}$ in diameter) were taken inside and outside the seagrass bed to determine the thickness of the sand overlaying the old marsh peat, grain size and organic content. The sand and old marsh peat layers in these cores were separated based on differences in grain size and sediment color. The 2 different layers were then put in separate, labeled plastic bags and taken to the laboratory for characterization of grain size and organic content (Erftemeijer \& Koch 2001). Dry and wet sieving (USA Standard Testing Sieve, American Society for Testing and Materials [ASTM] E-11 Specification, W. S. Tyler, -1 through $\geq 5 \Phi$ units) were used to characterize coarse $(\leq 3 \Phi)$ and fine $(>3 \Phi)$ grain size, respectively. Organic content analysis consisted of combustion at $450^{\circ} \mathrm{C}$ for $4 \mathrm{~h}$ (Barnstead Thermolye Furnace 30400). 


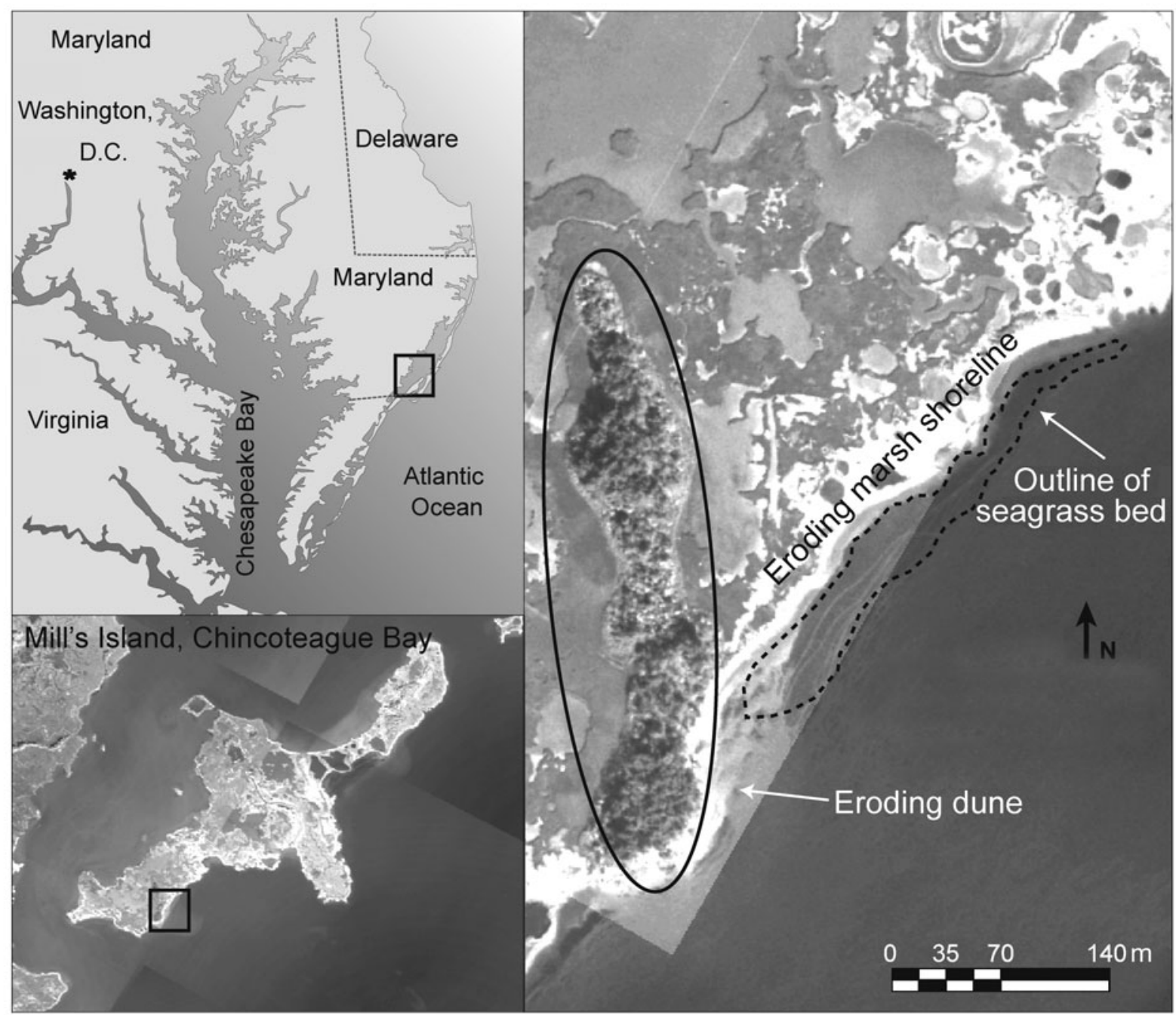

Fig. 1. Location of the study site at Mill's Island $\left(38^{\circ} 03^{\prime} \mathrm{N}, 75^{\circ} 18^{\prime} \mathrm{W}\right)$ in Chincoteague Bay on the eastern shore of Maryland, and location of the Zostera marina bed studied (dashed outline). Edge of the seagrass bed was determined by visually assessing a 2003 aerial photograph (courtesy of the Virginia Institute of Marine Science) for a change in color between the bed and bare sand. Shoreline retreat at this site has occurred at a rate of $0.59 \mathrm{~m} \mathrm{yr}^{-1}$ for the past century

In June 2005, the waters off the southeast shoreline of Mill's Island were surveyed for seagrass distribution along the $80 \mathrm{~cm}$ depth contour (maximum depth of distribution is $110 \mathrm{~cm}$ ). Fifteen points along the $80 \mathrm{~cm}$ depth contour that represented the range of sediment (sand, old marsh peat and sand overlaying old marsh peat) and seagrass shoot density (vegetated and unvegetated) combinations found at Mill's Island were chosen. At each point, GPS coordinates (eTrex), water depth (meter stick), seagrass species and shoot density $(25 \times 25 \mathrm{~cm}$ quadrat) were measured. Sediment samples were collected for analysis of thickness of the sand layer overlaying the old marsh peat and organic content, using the same methods as in 2004.

To determine whether plant biomass was affected by sediment organic content in situ, seagrass samples were taken at the same 15 points along the $80 \mathrm{~cm}$ depth contour where the sediment samples were also taken. At each location, 3 samples of seagrasses were collected with a $5 \mathrm{~cm}$ diameter core within $50 \mathrm{~cm}$ of where sediment samples were taken. All plant material was rinsed in seawater in a sieve prior to bagging to remove any sediment attached to the roots and rhizomes. Samples were taken back to the laboratory and refrigerated $\left(6^{\circ} \mathrm{C}\right)$ until samples were separated into aboveground and belowground biomass, placed in a drying oven $\left(50^{\circ} \mathrm{C}\right)$, dried to constant weight and weighed to determine biomass.

Due to the stratified nature of the sediment colonized by seagrasses at this site, an organic content value for the top $15 \mathrm{~cm}$ of sediment (maximum rhizosphere depth) was estimated for each sampling location. This value was then related to seagrass biomass. The depth of the rhizosphere was determined by measuring all 
root lengths $(\mathrm{n}=231)$ of 92 Zostera marina plants collected at 10 random sites within the seagrass bed. As rhizomes of $Z$. marina are normally buried, the maximum root length underestimates the rhizosphere depth. The equation used to determine the weighted estimate of sediment organic content $\left(\mathrm{OC}_{\text {est }}\right)$ in the seagrass rhizosphere was:

$$
\mathrm{OC}_{\mathrm{est}}=\left(F_{s} \times \mathrm{OC}_{s}\right)+\left(F_{\text {omp }} \times \mathrm{OC}_{\text {omp }}\right)
$$

where $F_{s}$ was the fraction (unitless) of the top $15 \mathrm{~cm}$ of sediment that was sand, $\mathrm{OC}_{s}$ was the percentage organic content (\%) of the sand, $F_{\text {omp }}$ was the fraction of the top $15 \mathrm{~cm}$ of sediment that was old marsh peat and $\mathrm{OC}_{\mathrm{omp}}$ was the percentage organic content of the old marsh peat. Therefore, as the $\mathrm{OC}_{\text {est }}$ increased, actual samples changed from sand only to sand overlaying old marsh peat to old marsh peat only.

Sediment organic content experiment. An outdoor mesocosm $(3.07 \mathrm{~m}$ long $\times 0.66 \mathrm{~m}$ wide $\times 0.60 \mathrm{~m}$ high $)$ with extensive aeration (using air stones) for carbon dioxide supply and water movement was used to determine the response of Zostera marina to different sediment organic contents. Use of a single mesocosm containing all organic content treatments ensured that nutrient concentrations in the water column were equal for all organic content treatments independent of nutrients possibly being released from the sediments into the water column. To obtain different sediment organic contents $(0.1,0.5,1.2,4.4$ and $5.9 \%)$, different types of sediments were mixed (Table 1). The degree of compaction of the experimental sediment (not quantified, only observed by touch) was different for all treatments. The $4.4 \%$ organic content treatment (100\% old marsh peat) was the most compacted as it was left in its natural state for the experiment. Three replicates of each treatment were used, totaling 15 compartments, each $25 \mathrm{~cm}$ long $\times 19 \mathrm{~cm}$ wide $\times 10.5 \mathrm{~cm}$ deep.

Table 1. Sources of sediment used to obtain a range of sediment organic content treatments for a mesocosm experiment. Beach dune sand obtained from Assateague State Park, MD; marsh dune sand obtained from Mill's Island, Chincoteague Bay, MD; old marsh peat obtained from subtidal area adjacent to Mill's Island, Chincoteague Bay, MD; and marsh sediment obtained from Horn Point Marsh, Cambridge, MD. Sediment was a mixture of decomposed marsh vegetation and soil

\begin{tabular}{|lcc|}
\hline $\begin{array}{l}\text { Treatment (\% organic } \\
\text { content } \pm \mathrm{SE} \text { ) }\end{array}$ & $\begin{array}{c}\text { Sediment } \\
\text { source 1 }\end{array}$ & $\begin{array}{c}\text { Sediment } \\
\text { source 2 }\end{array}$ \\
\hline $0.1 \pm 0.0$ & Beach dune sand & - \\
$0.5 \pm 0.0$ & Marsh dune sand & Old marsh peat \\
$1.2 \pm 0.0$ & Marsh dune sand & Old marsh peat \\
$4.4 \pm 0.2$ & Old marsh peat & - \\
$5.9 \pm 0.0$ & Old marsh peat & Marsh sediment \\
\hline
\end{tabular}

The sediments were placed in an indoor annular flume in December 2004 to allow for equilibration of geochemical gradients for 3 mo under continuous water flow $\left(10 \mathrm{~cm} \mathrm{~s}^{-1}\right.$ at sediment surface) and $20^{\circ} \mathrm{C}$. During this period the water (filtered Choptank River water, salinity $=10$ to 15 ) was changed weekly.

The compartments were then moved to the outdoor mesocosm in April 2005 for the start of the experiment. The mesocosm was covered with 2 layers of neutral density screening to prevent high water temperatures and to minimize epiphytic growth. Two air pumps (Optima, no. 807) provided carbon dioxide and water movement. There were no additional currents or waves generated in the mesocosm; therefore, conditions were characteristic of a sheltered site. Ambient estuarine (Choptank River) water was combined with Crystal Sea Marinemix (Marine Enterprise International) to raise the salinity to that of the collection site (salinity $=25$ ) and a $50 \%$ water change occurred weekly. Zostera marina seedlings (single shoots) from Chincoteague Bay were planted in the compartments (4 plants per compartment) and were allowed to grow for $8 \mathrm{wk}$. At the end of the experiment, all plant material was processed the same way as were field samples.

Additionally, at the end of the experiment sediment samples (1 per compartment) were taken for determination of nitrogen fixation, which was investigated in the 5 organic content treatments using the acetylene reduction assay to determine the rate of nitrogenase activity (Burns \& Hardy 1975, Capone 1982). Acetylene $\left(\mathrm{C}_{2} \mathrm{H}_{2}\right)$, generated by reacting calcium carbide with water, was added to gas-tight flasks containing sediment samples at a volume equal to approximately 10 to $15 \%$ of the gas phase volume. Acetylene is preferentially reduced to ethylene $\left(\mathrm{C}_{2} \mathrm{H}_{4}\right)$ by nitrogenase (the enzyme responsible for nitrogen fixation). Ethylene is readily detectable using gas chromatography-flame ionisation detection (GC-FID). To determine the ethylene formation over time, $0.10 \mathrm{ml}$ of gas from the headspace volume of the experimental flasks was withdrawn using a gas-tight syringe and analyzed on a Shimadzu 8A gas chromatograph (GC) with a HaySep A column equipped with an FID. The gas phase of each sample was measured over a $24 \mathrm{~h}$ time period to assess the rate of production of ethylene. Sample values were compared with a standard of known concentration of ethylene (100 ppm). Samples were run under both aerobic and anaerobic conditions to test for different nitrogenase activities by different diazotrophic bacterial populations, which can range from microaerophilic (low oxygen) to strictly anaerobic. Sediment treatments were amended with $30 \mu \mathrm{M}$ glucose as a labile organic source to simulate seagrass exudation and resulting nitrogen fixation, and organic carbon content was determined on amended samples. Anaer- 
obic samples were gassed for 3 to 4 min with a nitrogen-helium gas mixture to purge oxygen from the head space of the flask. The assays were maintained at constant ambient temperature $\left(\sim 25^{\circ} \mathrm{C}\right)$ in an environmental growth chamber. Benthic nitrogenase activity was normalized to sediment dry weight.

Statistical analysis. Data from the sediment organic content experiment were analyzed using ANOVA ( $\alpha=$ 0.05) in SAS 9.1. Aboveground biomass was tested across treatments, with biomass being the dependent variable and sediment organic content the independent variable. Homogeneity of variance was checked using Levene's test $(\alpha=0.05)$. Graphical representation of the data and the Shapiro-Wilk's test for normality showed all parameters to be non-normal and were log transformed. Transformed data were normally distributed and homogeneity of variances for all data was met. If significant differences were found using 1-way ANOVA, then factors were tested using the least squares method $(\alpha=0.05)$.

\section{RESULTS}

\section{Light availability}

Light attenuation coefficients off Mill's Island ranged from 1.2 to $3.5 \mathrm{~m}^{-1}$ with an average of $2.1 \pm 0.1 \mathrm{~m}^{-1}$ (mean $\pm \mathrm{SE}$ ). For locations where total depth $\leq 1.0 \mathrm{~m}$, i.e. in seagrass habitats, the average light attenuation coefficient was $1.9 \pm 0.1 \mathrm{~m}^{-1}$ while for locations where total depth $>1.0 \mathrm{~m}$, the average light attenuation coefficient was $2.1 \pm 0.1 \mathrm{~m}^{-1}$. Light levels ranged between 100 and $1870 \mu \mathrm{mol} \mathrm{m} \mathrm{m}^{-2} \mathrm{~s}^{-1}$ at 1 and $0.2 \mathrm{~m}$ depth, respectively. The spatial light pattern did not show higher turbidity near shore but did show localized areas with higher turbidity (possibly a result of eddies).

\section{Field surveys}

The sand off Mill's Island was dominated by fine sand (125 to $250 \mu \mathrm{m}, \Phi=3$ ) and the old marsh peat was characterized by silt plus clay ( $<63 \mu \mathrm{m}, \Phi \geq 5$, Fig. $2 \mathrm{a})$. Samples that consisted of sand overlaying old marsh peat had a thin $(\sim 1 \mathrm{~cm})$ mixed layer between both sediment types (represented by SE values in Fig. 2a). Sediment organic content increased with silt plus clay content (Fig. 2b).

The seagrass bed consisted exclusively of Zostera marina although other seagrass beds in the area often have a fringe of Ruppia maritima along the shallow edge of the bed. The relationship between $Z$. marina shoot density and sediment organic content showed a threshold response with a $4 \%$ organic content critical limit (Fig. 3a). Alternatively, a linear correlation
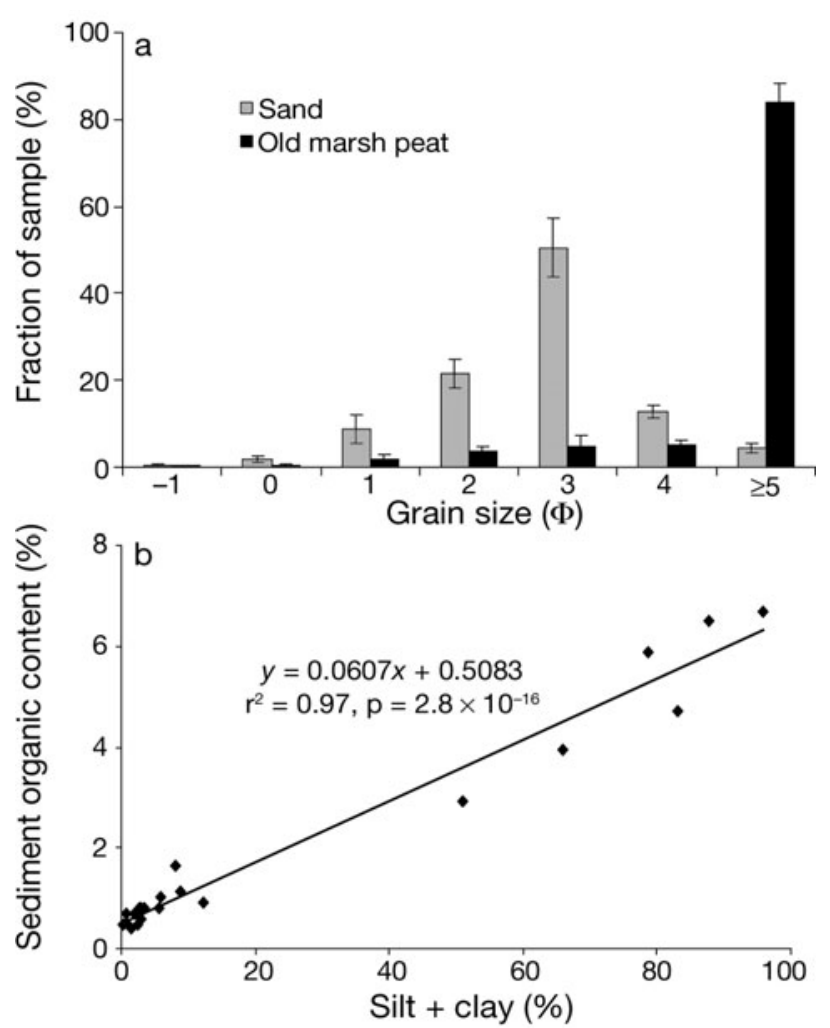

Fig. 2. (a) Grain size distribution of sand and old marsh peat at Mill's Island. Error bars $=$ SE. (b) Sediment organic content as a function of the silt plus clay fraction

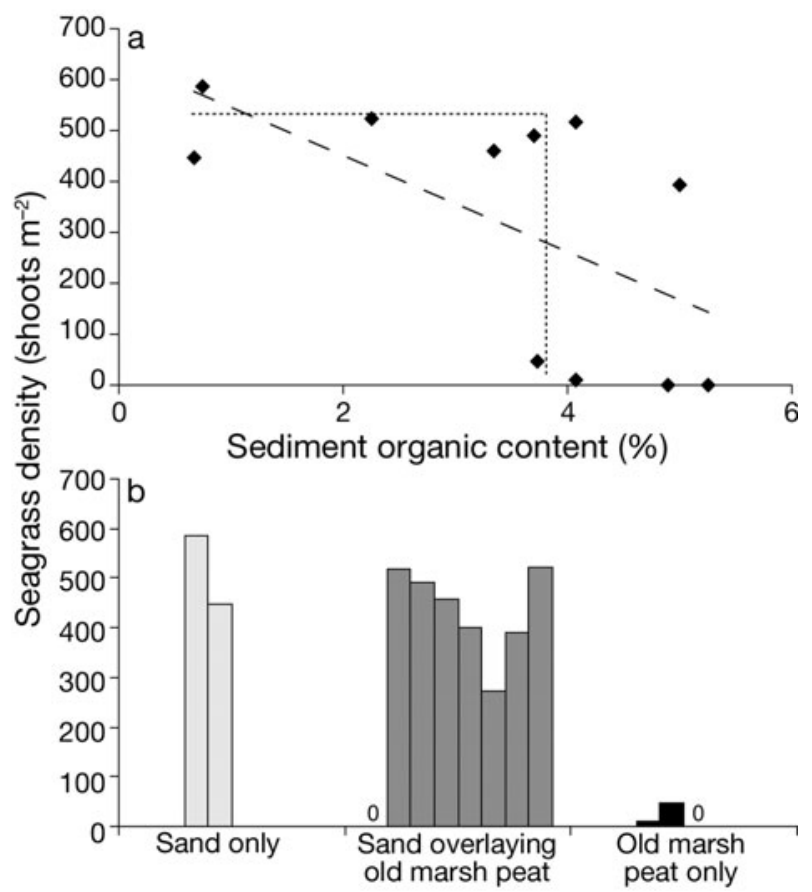

Fig. 3. Zostera marina. (a) Shoot density as a function of sediment organic content in the rhizosphere (top $15 \mathrm{~cm}$ ) at Mill's Island. Dotted line represents possible threshold response while dashed line represents the best linear fit. (b) Shoot density grouped into categories of sediment type 
through the data showed a negative function with a low $r^{2}$ value $\left(r^{2}=0.38\right.$, Fig. 3a). Most sites $(n=9)$ that had low organic content (sand and sand overlaying old marsh peat) were vegetated, with average shoot densities of $427 \pm 61$ shoots $\mathrm{m}^{-2}$ (Fig. $3 \mathrm{~b}$ ). Sites that had high organic content (old marsh peat only) had lower shoot densities or were unvegetated (average of $25 \pm$ 15 shoots $\mathrm{m}^{-2}, \mathrm{n}=3$, Fig. 3b). Average aboveground and belowground biomass decreased linearly with increasing sediment organic content $\left(\mathrm{r}^{2}=0.39\right.$ and 0.51 , respectively, Fig. 4).

\section{Sediment organic content experiment}

In general, all growth parameters in the mesocosm experiment (aboveground biomass, $\mathrm{r}^{2}=0.84$; belowground biomass, $\mathrm{r}^{2}=0.91$; leaf length, $\mathrm{r}^{2}=0.84$; root length, $\left.r^{2}=0.51\right)$ tended to increase with sediment organic content up to the highest treatment (5.9\%, Fig. 5). This observation was opposite to field trends. The ratio of leaf length to root length increased with increasing sediment organic content (Fig. 6). Rates of nitrogenase activity peaked in the $4.4 \%$ organic content treatment under aerobic conditions and in the $1.2 \%$ treatment under anaerobic conditions, but decreased at higher organic content $(5.9 \%)$ under both conditions (Fig. 7).

\section{Statistical analysis}

There were significant differences $(p<0.0001)$ between sediment organic content treatments for aboveground and belowground biomass (Table 2). The

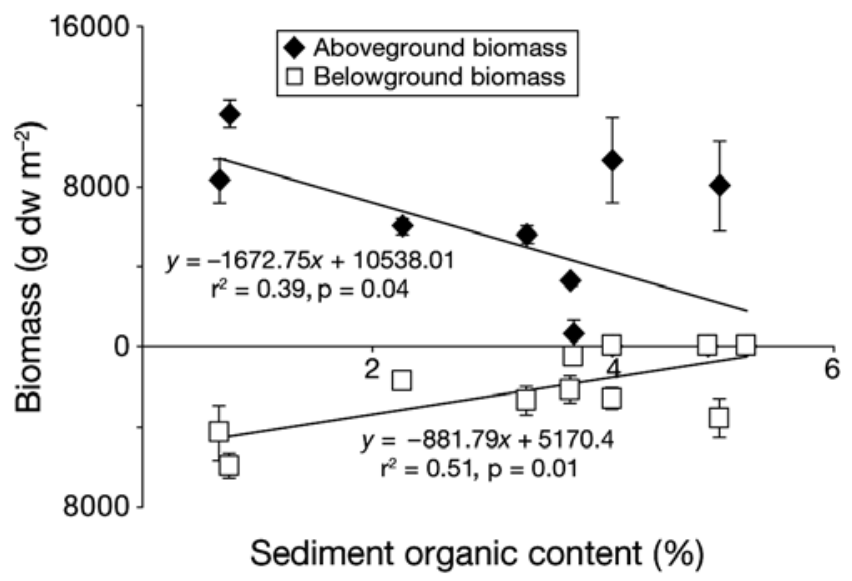

Fig. 4. Zostera marina. Average aboveground and belowground biomass as a function of sediment organic content in the rhizosphere (top $15 \mathrm{~cm}$ ) at Mill's Island. Error bars $=\mathrm{SE}$; $\mathrm{dw}=$ dry weight. Note that $y$-axis is positive to both sides of zero
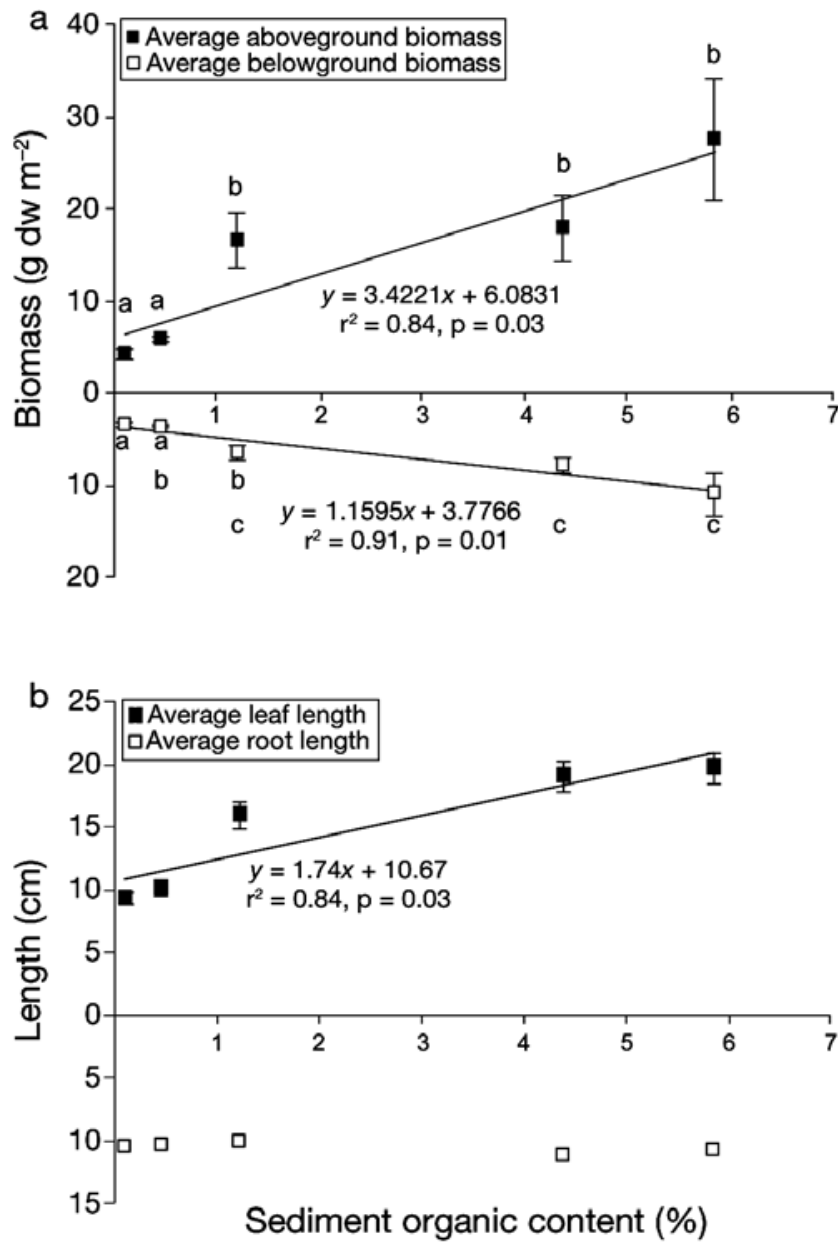

Fig. 5. Zostera marina. (a) Average aboveground and belowground biomass of plants grown in sediments with organic content between 0.1 and $5.9 \%$ in a mesocosm experiment. (b) Average leaf and root length of plants grown in sediments with different organic contents in a mesocosm experiment. Error bars = SE (not shown for root length due to small SE); $\mathrm{dw}=$ dry weight. Note that $y$-axis is positive to both sides of zero

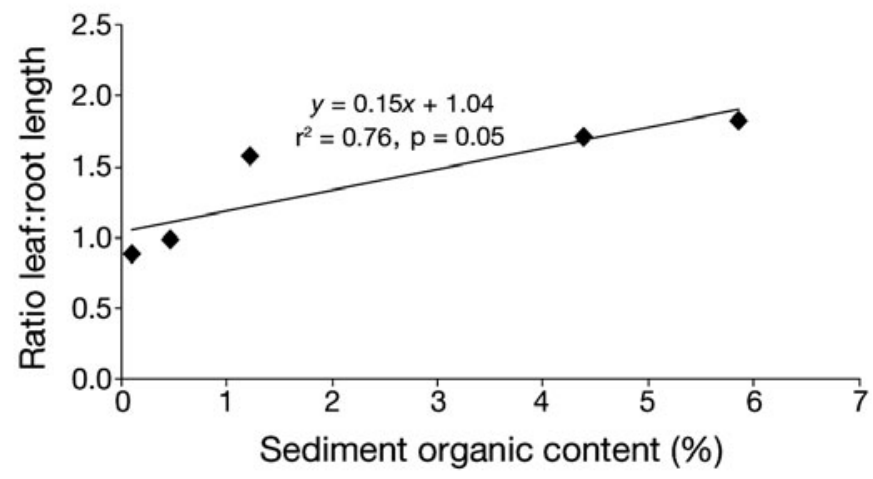

Fig. 6. Zostera marina. The ratio of leaf length to root length of plants grown in sediments with different organic contents in a mesocosm experiment 
aboveground biomass separated into 2 groups: (1) the $0.1 \%$ and $0.5 \%$ treatments, which were not significantly different from each other but were significantly different from the 3 higher organic content treatments, and (2) the 3 higher organic treatments, which were not significantly different from each other $(p=0.05)$. The belowground biomass separated into 3 groups: (1) the $0.1 \%$ and $0.5 \%$ organic content treatment,

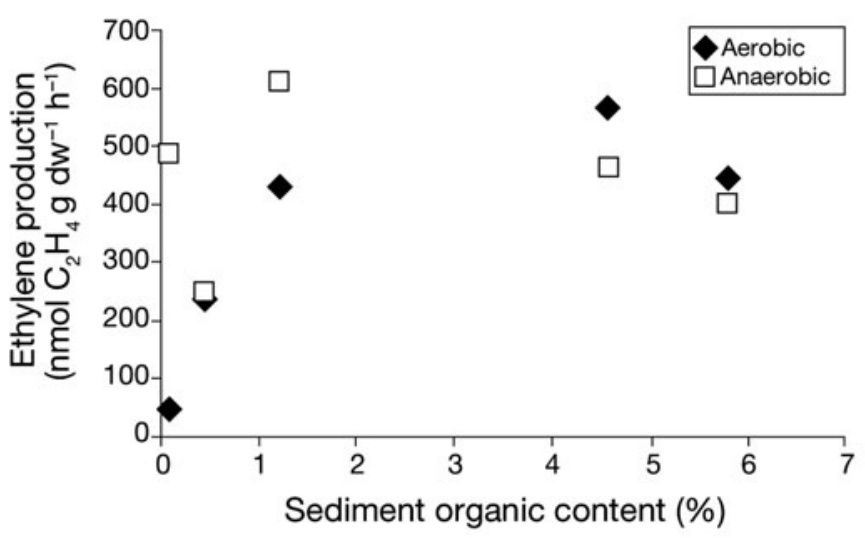

Fig. 7. Nitrogen fixation (nmol $\mathrm{C}_{2} \mathrm{H}_{4}$ [g dry weight sediment ${ }^{-1}$ $\mathrm{h}^{-1}$ ) in sediments with different organic contents in the mesocosm experiment. Samples were analyzed under both aerobic and anaerobic conditions

Table 2. One-way ANOVA $(\alpha=0.05)$ and pairwise comparisons for aboveground and belowground biomass in the mesocosm experiment. Samples sharing the same letter are not significantly different at $\mathrm{p}=0.05$. ( $\mathrm{ns}=$ not significant $)$

\begin{tabular}{|c|c|c|c|c|c|}
\hline $\begin{array}{l}\text { Sources of } \\
\text { variation }\end{array}$ & df & & $\begin{array}{l}\text { Mean } \\
\text { square }\end{array}$ & $F$ & $\mathrm{p}$ \\
\hline \multicolumn{6}{|l|}{ Aboveground } \\
\hline Organic matter & \multicolumn{2}{|l|}{4} & 0.3537 & \multirow[t]{5}{*}{19.68} & \multirow[t]{5}{*}{$<0.0001$} \\
\hline Residuals & \multirow{2}{*}{\multicolumn{2}{|c|}{$\begin{array}{l}10 \\
14\end{array}$}} & 0.0153 & & \\
\hline Total & & & & & \\
\hline Transformation & \multicolumn{3}{|c|}{$\ln (x+1)$} & & \\
\hline Levene's test & \multicolumn{3}{|c|}{0.2996 (ns) } & & \\
\hline \multicolumn{6}{|l|}{ Belowground } \\
\hline Organic matter & \multirow{2}{*}{4} & & \multirow{2}{*}{$\begin{array}{l}0.1298 \\
0.0096\end{array}$} & 13.50 & 0.0005 \\
\hline Residuals & & & & & \\
\hline Total & 14 & & & & \\
\hline Transformation & \multicolumn{3}{|c|}{$\ln (x+1)$} & & \\
\hline Levene's test & \multicolumn{3}{|c|}{0.1917 (ns) } & & \\
\hline \multicolumn{6}{|c|}{ Pairwise comparison } \\
\hline Rank of the me & ans 1 & 2 & 3 & 4 & 5 \\
\hline SOC (\%) & 0.1 & 0.5 & 1.2 & 4.4 & 5.9 \\
\hline \multicolumn{6}{|l|}{ log biomass } \\
\hline Aboveground & -0.6071 & -0.7550 & $0-1.2002$ & -1.2306 & -1.4155 \\
\hline Belowground & -0.5455 & -0.5668 & $8-0.8140$ & -0.8952 & -1.0226 \\
\hline
\end{tabular}

which were not significantly different from each other, (2) the belowground biomass in the $0.5 \%$ and $1.2 \%$ organic content treatments, which were not significantly different from each other, and (3) the belowground biomass in the 1.2, 4.4 and $5.9 \%$ organic content treatments, which were not significantly different from each other $(p=0.05)$. See Table 2 for all pairwise comparisons.

\section{DISCUSSION}

Despite the highly erosional shoreline at Mill's Island in Chincoteague Bay, light was not limiting to seagrasses at the study site. Turbidity was not highest near shore where seagrasses are located. Instead, turbid water seemed to be transported offshore by eddies. The presence of a healthy seagrass bed was further evidence that sufficient light was available to support seagrass growth.

Although initially it may seem that light was not a limiting factor in the area and that sediments must be limiting seagrass distribution, one must consider what came first, the seagrasses or the sand. Seagrasses are well known for their capacity to trap particles (Fonseca \& Fisher 1986) due to the reduction of current velocity and attenuation of wave energy (Fonseca \& Cahalan 1992) by the vegetation. It follows that perhaps preexisting seagrasses led to the deposition of sand in the vegetated area. This hypothesis is unlikely as Zostera marina disappeared from Chincoteague Bay in the 1930s due to wasting disease (Koch \& Orth 2003). Recovery started to accelerate in the 1980 s, but beds were restricted to the eastern shore of the bay. Only in 1996 did seagrasses appear on the western side of the bay where the study site is located. If all the sand currently found overlaying the old marsh peat in the seagrass bed (more than 50 to $100 \mathrm{~cm}$ in some locations) was deposited in the last $10 \mathrm{yr}$, seagrasses would have been buried by depositional rates of 5 to $10 \mathrm{~cm} \mathrm{yr}^{-1}$ or more. Even small levels of burial $(25 \%$ of photosynthetic tissue) can be detrimental to $Z$. marina (Mills \& Fonseca 2003). Therefore, it is unlikely that the sand currently found in the bed studied is a result of trapping by seagrass leaves. This is also supported by the fact that seagrass density in the area significantly declines during the winter season but the sand remains. Instead, it is likely that the accumulation of sand allowed the seagrasses to colonize the area.

While our field results suggest that excessive organic matter can be detrimental to Zostera marina, our mesocosm results suggest the opposite. Our mesocosm experiment shows that a lack of sufficient organic matter can be detrimental to seagrass growth, as seen by the reduced biomass found in $Z$. marina grown in sedi- 
ments with $\leq 0.5 \%$ organic content. These results agree with other studies in which sandy sediments were nutrient limiting (Short 1987). In contrast, the highest biomass in the field was found in sediments with $<1 \%$ organic content and seagrasses were absent from sediments with organic content $>4 \%$. This inconsistency suggests that sediment organic content is not the only factor limiting seagrasses in situ and that one or more additional factors need to be considered when evaluating the effect of sediment organic content on seagrass growth and distribution. Hydrogen sulfide can be detrimental to seagrass growth; however, hydrogen sulfide concentrations were below toxic levels in the field $(<1000 \mu \mathrm{M}$ in the rhizosphere, Wicks 2005).
Previous research, as well as the present study, clearly show that sediment organic content has a major effect on seagrass morphology. Thalassia testudinum grown in low porewater ammonium $(\sim 30 \mu \mathrm{M})$ sediments (i.e. low organic content) had significantly shorter and narrower leaves than $T$. testudinum grown in high porewater ammonium $(\sim 100 \mu \mathrm{M})$ sediments (i.e. high organic content, Lee \& Dunton 2000). Additionally, when plants grown in low organic content sediments were fertilized, they increased in aboveground biomass, but not belowground biomass, resulting in a significant difference in the ratio of aboveground to belowground biomass between fertilized and unfertilized plots (Lee \& Dunton 2000). Zostera marina grown
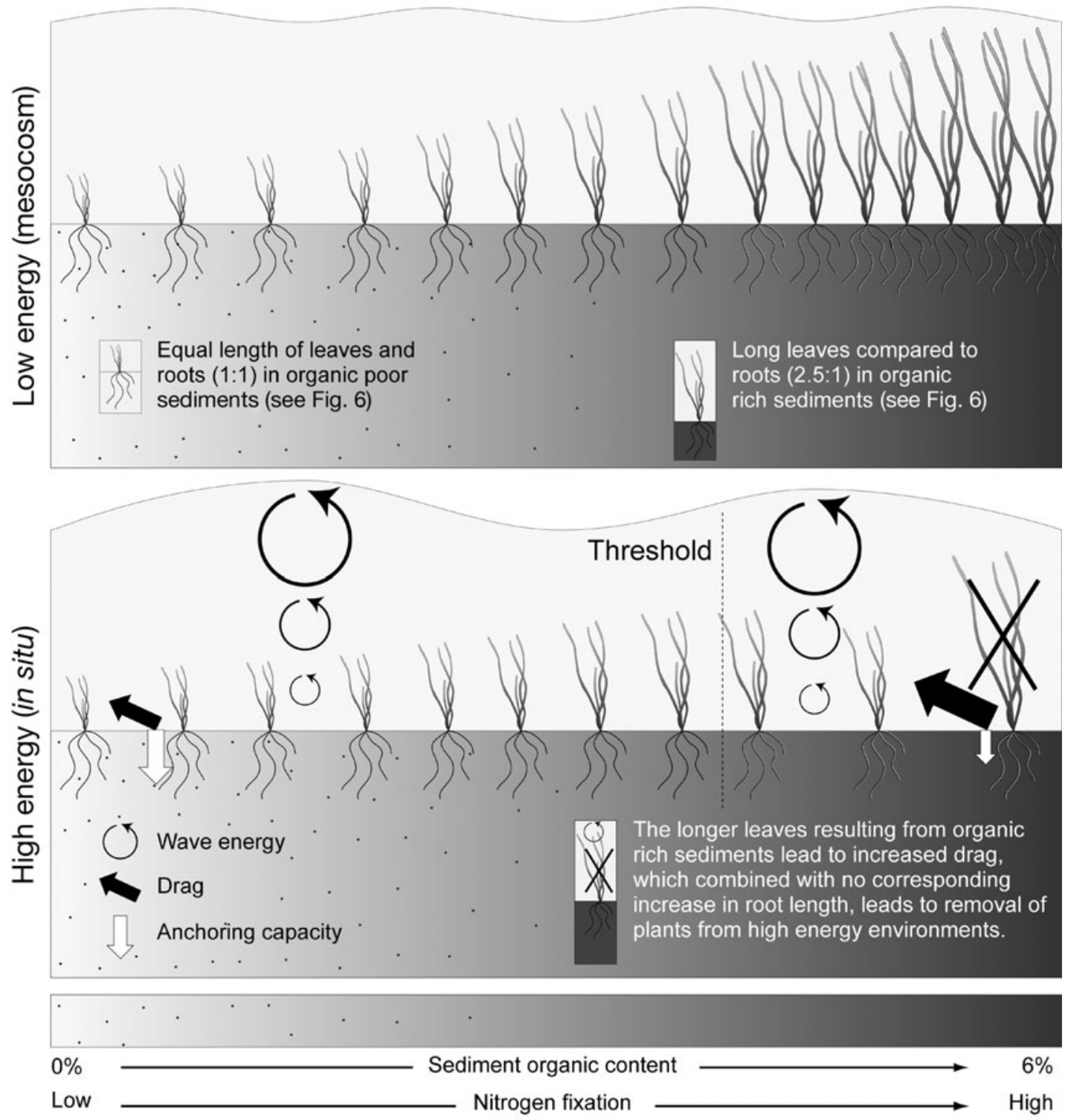

Fig. 8. Zostera marina. Conceptual diagram describing the relationship of sediment organic content and nitrogen fixation with seagrass biomass and length in low and high energy environments 
in mesocosms in Alaska was larger in muddy sediments (i.e. higher organic content) than in sandy sediments, but there were fewer root hairs (Short 1983). This finding suggests that plenty of nutrients were available so the plants did not need more root hairs to take up nutrients. Z. marina grown in our mesocosm followed similar patterns developing short leaves when sediment organic content was low and long leaves when sediment organic content was high (Fig. 8). This increase in aboveground biomass as a function of sediment organic content is directly linked to sediment nutrient availability, e.g. porewater nitrogen and phosphorus (Wicks 2005). It may also be linked to nitrogen fixation by root-associated bacteria, as nitrogen fixation under aerobic conditions increased from low to high organic sediments (Fig. 7). When compared with leaf length, root length did not show a proportional increase (Fig. 5b), leading to plants with disproportionately long leaves and short roots in organic rich sediments (Fig. 6). In contrast, in sediments with organic content $<1 \%$ leaf and root length were similar.

The short leaves and long roots of $Z$. marina grown in low organic content sediments are likely to lead to low drag exerted on the leaves and a high anchoring capacity of the roots. In contrast, the morphology of $Z$. marina grown in sediments with high organic content (long leaves and short roots) leads to a poor anchoring capacity and high drag being exerted on the leaves. Therefore, we hypothesize that, due to sediment-induced morphology, Z. marina growing in sand is more likely to withstand hydrodynamic forces such as currents and waves than are plants growing in muddy sediments (Fig. 8).

Fine organic sediments are usually found in relatively quiescent hydrodynamic conditions, while coarser, lower organic sediments are characteristic at sites with strong currents and/or waves. Under these conditions, plants will always develop appropriate morphologies: high-drag plants with low anchoring capacity under quiescent conditions (sediment with high organic content) and low-drag plants with high anchoring capacity under hydrodynamically active conditions (sediment with low organic content). This has been shown for Zostera noltii (Peralta et al. 2005). In contrast, at our study site organic rich sediments are found in an area with sufficiently strong waves to erode the shore. Any plants able to grow in these sediments develop a morphology that may be unsuitable (high drag and low anchoring capacity) for the local hydrodynamic conditions. It follows that they are more likely to be uprooted. Dislodgement may also explain why seagrass shoot density is inversely proportional to sediment organic content and why seagrasses are absent from sediments with more than $4 \%$ organic content in situ (Fig. 3a). This agrees with the $5 \%$ threshold suggested in Koch (2001) and sediment organic content observed in other studies. For example, at a site near Fyn, Denmark, Z. marina is found growing in sediments with an organic content of $9.93 \%$ (Holmer \& Laursen 2002), but a more typical organic content for organic rich sediments in $Z$. marina beds is around 3\% (Holmer \& Laursen 2002, van Katwijk \& Wijgergangs 2004). These studies did not report hydrodynamic conditions at the study sites.

In summary, sediment organic content affects Zostera marina growth, but its importance in seagrass distribution may only be fully understood when local hydrodynamic conditions are also taken into consideration. This hypothesis needs to be investigated further. Best growing conditions in the field and in the mesocosm experiment occurred when sediment organic content was between $0.5 \%$ and approximately $4 \%$. This was also the range over which nitrogen fixation in the sediment was highest. Organic contents of $<0.5 \%$ are likely to be nutrient limiting to $Z$. marina while sediment organic contents of $>4 \%$ are not limiting per se. They only appear to be limiting when organic rich (4 to $6 \%$ ) sediments are found in hydrodynamically active areas, leading to a mismatch between plant morphology and the physical environment causing seagrasses to be uprooted (Fig. 8).

Acknowledgements. We thank W. Severn for his help with field and laboratory research. This research was supported in part by Horn Point Laboratory, University of Maryland Center for Environmental Science (UMCES), the National Oceanic and Atmospheric Administration and the Maryland Sea Grant, National Science Foundation sponsored Research Experience for Undergraduates (REU) Program. This paper is UMCES contribution no. 4234.

\section{LITERATURE CITED}

Berner RA (1977) Stoichiometric models for nutrient regeneration in anoxic sediments. Limnol Oceanogr 22:781-786

> Brüchert V, Pratt LM (1996) Contemporaneous early diagenetic formation of organic and inorganic sulfur in estuarine sediments from St. Andrew Bay, Florida, USA. Geochim Cosmochim Acta 60:2325-2332

Burns RC, Hardy RW (1975) Nitrogen fixation in bacteria and higher plants. Springer Verlag, New York

- Capone DG (1982) Nitrogen fixation (acetylene reduction) by rhizosphere sediments of the eelgrass Zostera marina. Mar Ecol Prog Ser 10:67-75

Carlson PR, Yarbro LA, Barber TR (1994) Relationship of sediment sulfide to mortality of Thalassia testudinum in Florida Bay. Bull Mar Sci 54:733-746

den Hartog C (1970) The sea-grasses of the world. NorthHolland Publishing, Amsterdam

> Dennison WC, Orth RJ, Moore KA, Stevenson JC and others (1993) Assessing water quality with submersed aquatic vegetation: habitat requirements as barometers of Chesapeake Bay health. Bioscience 43:86-94

> Duarte CM (1991) Seagrass depth limits. Aquat Bot 40: 363-377 
Erftemeijer PLA, Koch EW (2001) Sediment geology methods for seagrass habitat. In: Short FT, Coles RG (eds) Global seagrass research methods. Elsevier Science, London, p 345-367

Fonseca MS, Bell SS (1998) Influence of physical setting on seagrass landscapes near Beaufort, North Carolina, USA. Mar Ecol Prog Ser 171:109-121

Fonseca MS, Cahalan JA (1992) A preliminary evaluation of wave attenuation by four species of seagrass. Estuar Coast Shelf Sci 35:565-576

Fonseca MS, Fisher JS (1986) A comparison of canopy friction and sediment movement between four species of seagrass with reference to their ecology and restoration. Mar Ecol Prog Ser 29:15-22

Holmer M, Laursen L (2002) Effect of shading of Zostera marina (eelgrass) on sulfur cycling in sediments with contrasting organic matter and sulfide pools. J Exp Mar Biol Ecol 270:25-37

Holmer M, Andersen FO, Nelsen SL, Boschker HTS (2001) The importance of mineralization based on sulfate reduction for nutrient regeneration in tropical seagrass sediments. Aquat Bot 71:1-17

Koch EW (2001) Beyond light: physical, geological and geochemical parameters as possible submersed aquatic vegetation habitat requirements. Estuaries 24:1-17

Koch MS, Erskine JM (2001) Sulfide as a phytotoxin to the tropical seagrass Thalassia testudinum: interactions with light, salinity and temperature. J Exp Mar Biol Ecol 266: 81-95

Koch EW, Orth RJ (2003) The seagrasses from the midAtlantic coast of the United States. In: Green EP, Short FT (eds) World atlas of seagrasses. University of California Press, Berkeley, CA, p 216-223

Lee KS, Dunton KH (2000) Effects of nitrogen enrichment on biomass allocation, growth, and leaf morphology of the seagrass Thalassia testudinum. Mar Ecol Prog Ser 196:39-48

Mills KE, Fonseca MS (2003) Mortality and productivity of eelgrass Zostera marina under conditions of experimental

Editorial responsibility: Otto Kinne,

Oldendorf/Luhe, Germany burial with two sediment types. Mar Ecol Prog Ser 255: 127-134

Murray L, Dennison WC, Kemp WM (1992) Nitrogen versus phosphorus limitation for growth of an estuarine population of eelgrass (Zostera marina L.). Aquat Bot 44:83-100

> O'Neil JM, Capone DG (1989) Nitrogenase activity in tropical carbonate marine sediments. Mar Ecol Prog Ser 56: 145-156

Peralta G, Brun FG, Hernández I, Vergara JJ, Pérez-Lloréns JL (2005) Morphometric variations as acclimation mechanisms in Zostera noltii beds. Estuar Coast Shelf Sci 64: 347-356

Perry CJ, Dennison WC (1999) Microbial nutrient cycling in seagrass sediments. AGSO J Aust Geol Geophys 17: $227-231$

> Rosen PS (1980) Erosion susceptibility of the Virginia Chesapeake Bay shoreline. Mar Geol 34:45-59

> Short FT (1983) The seagrass, Zostera marina L.: plant morphology and bed structure in relation to sediment ammonium in Izembek Lagoon, Alaska. Aquat Bot 16:149-161

Short FT (1987) Effects of sediment nutrients on seagrasses: literature review and mesocosm experiment. Aquat Bot $27: 41-57$

Stevenson JC, Kearney MS, Koch EW (2002) Impacts of sea level rise on tidal wetlands and shallow water habitats: a case study from Chesapeake Bay. In: McGinn NA (ed) Fisheries in a changing climate. Am Fish Soc Symp 32, Bethesda, MD, p 23-36

> van Katwijk MM, Wijgergangs LJM (2004) Effects of locally varying exposure, sediment type and low-tide water cover on Zostera marina recruitment from seed. Aquat Bot 80: $1-12$

Wazniak CE, Hall MR (2005) Maryland's coastal bays: ecosystem health assessment 2004. Md Dep Nat Resour Tidewater Ecosyst Assess DNR-12-1202-0009, Annapolis, MD

Wicks EC (2005) The effect of sea level rise on seagrasses: Is sediment adjacent to retreating marshes suitable for seagrass growth? MS thesis, University of Maryland, College Park

Submitted: November 3, 2007; Accepted: December 10, 2008 Proofs received from author(s): March 2, 2009 